\title{
Historien om en gammel kanon
}

\author{
Af F. Matzen.
}

En af fortidens mindst omtalte våbenarter er roflotillen, der bestod af bombekanonchalupper, bombekanonjoller samt almindelige kanonchalupper og -joller. For Danmarks vedkommende tog bygningen af disse fartøjer navnlig fart efter ranet af flåden 1807, og disse små, let håndterlige, ikke ret dybtgående skibe kom til at spille en fremtrædende rolle såvel i søkrigen mod England som $\mathrm{i}$ treårskrigen og sidst $\mathrm{i}$ 1864, hvor den navnkundige kaptajnløjtnant Hammer var chef for kanonbådsflotillen ved Slesvigs vestkyst. Søfartsnationer som Italien, Frankrig, England, U.S.A., Prøjsen, Sverige og Danmark benyttede sig alle af disse fartøjer. Allerede for 1800 -tallet blev de af begge parter $i$ den amerikanske frihedskrig anvendt på Lake Champlain, og i 1805, i krigen mod de tunesiske barbarer, sejlede 8 amerikanske kanonbåde, kun 50 fod lange, fra Hampton Roads for at støde til den amerikanske flåde ud for Tripolis. De 7 nåede velbeholdne over Atlanterhavet, 1 forsvandt sporløst. De var konstrueret på basis af den såkaldte Messinakanonbåd med parancelle rig. ${ }^{1}$

Den oprindelige danske kanonbådstype har fundet vej hertil fra Middelhavet via Sverige, idet den da verdenskendte svenske skibskonstruktør Chapman udviklede sin egen type $i$ form af de såkaldte skærgårdsgalejer, hvis forbillede var hentet fra Middelhavet, og derefter de svenske skærgårdskanonbåde. Danmark ejede en hel del af disse såkaldte chapmanske kanonbåde, som under treårskrigen dog enten var oplagt eller blev ombygget til transportfartøjer, hvorimod flåden udrustede 42 bombekanonchalupper og 20 bombekanonjoller af den danske flådes geniale skibsbygmester Schifters konstruktion. De forte luggersejl og var bemandet med henholdsvis 64 mand og 30 årer samt 24 mand og 18 årer. Armeringen bestod af 60-pundige bombekanoner, 24pundige kanoner og 4-pundige haubitser. Heldigvis har datidens 


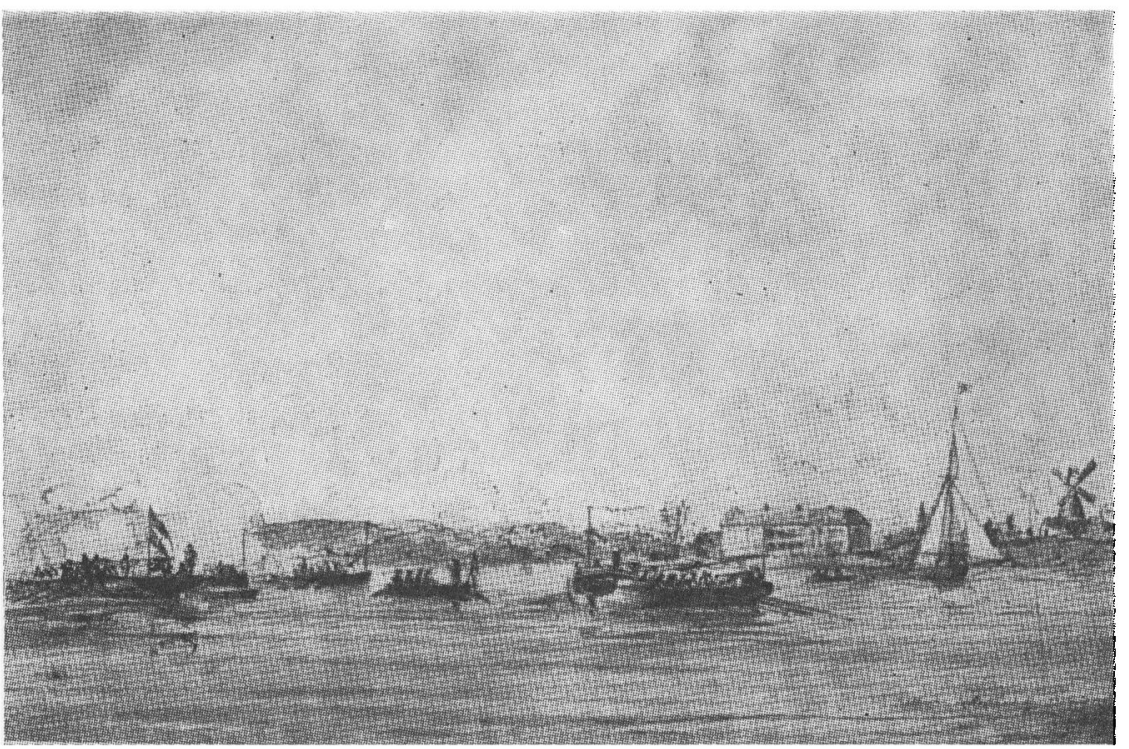

Danske og prøjsiske kanonbåde $i$ kamp $i$ Alssund ud for Sandbjerg Slot den 13. april 1849. Til venstre en dansk, derefter to prøjsiske kanonbäde, der affyrer deres kanoner. Den store rochallup udfor slottet er dansk.

Efter tegning af Emanuel Larsen. (Frederiksborg museet).

malere efterladt sig en hel del udmærkede billeder af disse små krigsfartøjer, der bl. a. i krigen 1807-14 ikke lod fjenden få ro hverken nat eller dag. De dukkede frem af deres skjul i bugter og vige og angreb den overlegne modstander hurtigt og dristigt, de erobrede 7 brigger og 1 kutter, sænkede 2 kuttere og skød 1 linieskib og 1 fregat kassable. Danskernes tab i materiel var 14 kanonbåde. Blandt de bedste fremstillinger fra den periode regnes Chr. Mølsteds maleri »En engelsk brig erobres«. I det hele laget er billedmateriellet de lettest tilgængelige overleveringer fra hine tider. Et maleri af Vilh. Melbye gengiver således en episode fra den 11. marts 1864, da panserskonnerten "ABSALON" havde taget en ved Hardeshøj grundstødt kanonbåd på slæb, medens granaterne fra de tyske batterier på Sundevedsiden slår op rundı omkring dem.

Om kanonbådsoperationer i de sønderjyske farvande hører vi første gang under treårskrigen og da såvel fra dansk som fra 
prøjsisk side, idet oprørerne havde udrustet $i$ hvert fald 11 "krigsloggere", som de kaldte deres kanonbåde, vistnok fordi deres rig lignede fiskerloggernes fra Bretagne. De havde en besæetning på 60 mand og var armeret med en kanon for og agter. Den 17. august 1848, da fregatten "NAJADEN" var engageret $i$ en formidabel kanonduel med oprørernes batterier inde på Holnæs, hidkaldte kanonilden kanonjollerne fra Egernsund, de kom uventet roende frem af morgendisen inde under landgrundene ved Holnæs, og snart efter hørtes drønene af deres skyts, der blev rettet mod fjendens flanke og tvang hans feltbatterier til at opgive deres stillinger og tage flugten.

Iøvrigt beretter smedens søn fra Nordborg, Claus Grønn, der senere blev sømand og guldgraver i Australien, i sine »Erindringer fra Sø og Land " livligt og detailleret om, hvad han i 1848, 16 år gammel, under løjtnant Rothes kommando oplevede som krigsfrivillig med kanonjolle $\mathrm{Nr} .2$ i de snævre farvande ved Gråsten og Egernsund, hvor der udkæmpedes adskillige drabelige batailler mellem kanonfartøjerne og oprørerne i land. Claus Grønns personlige oplevelser, som blev udgivet på dansk i Australien, er et værdifuldt historisk bidrag om denne epoke.

I Alssund havde kanonbådene, såvel under treårskrigen som i 1864, forskellige ankerpladser - således ved Stegsvig - Hardeshøj, i Augustenborg fjord og, den mest omtalte, ved Arnkilsøre, hvor der var bygget lejr og anlagt havn på strandbredden. Maleren Emanuel Larsen, der levede fra 1823 til 1859 , har i en tegning levendegjort en kanonbådstræfning i Alssund den 13. april 1849; den synes at have fundet sted på Sundevedsiden ud for Sandbjerg Slot. Fra samme kunstners hånd foreligger endvidere et herligt oliemaleri af en dansk kanonbåd for fulde sejl i Alssund 1848, og i relation til den efterfølgende beretning er det interessant at påvise, at kanonbåden er malet liggende tæt ind under land ved Stevning Næs, »Stevninghoj « på lokaldialekten, Als, med Sandvig i baggrunden.

En tilfældig bemærkning af kaptajn Warming på Alnor om, at hans far med sin galease "christine « havde bjærget en gammel kanon ud for Stevning Næs i oktober 1898, afstedkom efterforskningen af kanonbådsaktionerne i Alssund i længst henrundne dage. Et falmet, udvisket fotografi fra 1898 blev fundet 


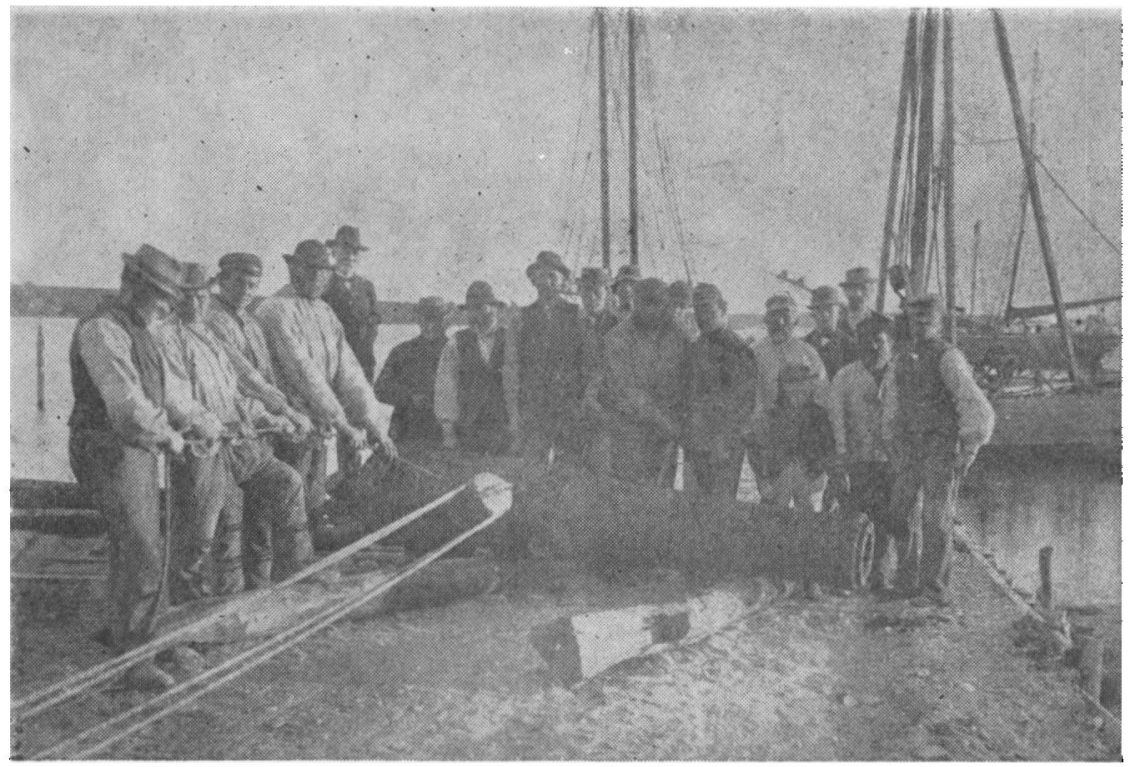

$P a$ Nis Nissens bro ved Stevning Nor den 1. oktober 1898. Den gamle kanon er sat velbeholden $i$ land efter at have ligget på havets bund $i$ So år. (Billedet er taget af snedker og kobmand $i$ Stevning, Chresten Jorgensen, fader til stifteren af firmaet Brdr. Jorgensen i Sonderborg).

frem, en kyndig fotograf fremtryllede den 67 år gamle landsætningsscene af kanonen på Nis Nissens bro i Stevning Nor, hvor slægten Nissen i generationer havde ejet bro, kro og forretning. Slægtens ældste nulevende medlem, den 75 årige amtskasserer $i$ D.S.K., Nis Nissen, Bækgade, Nordborg, blev opsporet, og snart kunne historien stykkes sammen. Hans bedstefar, efter hvem han var opkaldt, var født i 1817, og han blev ihærdigt ved med at påstå, at der lidt nord for Stevning Nor, ud for "Stevninghoj", lå en stor kanon, som han havde set blive kastet $i$ vandet fra en kanonbåd under treårskrigen. Folk trak efterhånden lidt på smilebåndet ved gamlingens historie, men han blev ved sit. Så, i 1898, da han var 81 år gammel, kommer dykker Gidal fra Egernsund ind til Stevning Nor med sin rambuk. Han var vendt hjem fra sin færden på de store have, og havde nu overtaget vedligeholdelsen af dampskibsbroerne for Bruhns fjordrederier. Da så Nis 
Nissen har fortalt Gidal sin historie om kanonen, trækker denne i sin dykkerdragt, går ned på det anviste sted - og finder kanonen. Det var den 1. oktober 1898. Kanonen var for tung til at kunne loftes med Gidals rambuk, men så kommer til alt held skipper Warming fra Dalsgård med sin selvbyggede galease "CHRISTINE « ind til Stevning Nor med en ladning korn til Nis Nissens søn. Da Gidal har fortalt Warming om kanonen, som han har lokaliseret, men ikke kan få op, svarer Warming omgående: "Vil du ned og slå den på, tager jeg den op «. Som sagt, så gjort. Det beviser det gamle fotografi, som moderne fotografkunst igen har kaldt til live. I forgrunden ses den ret store kanon, der netop er halet i land fra CHRISTINE « ved hjælp af en svær talje. Bag ved kanonen står 19 mand, hvoraf nu kun een, den da niårige Nis Nissen, er i live. Gamlingen yderst til højre med den halvlange pibe $\mathrm{i}$ munden er hans 81-årige bedstefar, som sikkert nok har været stolt over at se beviset for sin påstand bragt godt $i$ land. Midt på billedet, med venstre ben på kanonen, står dykker Gidal og ved hans side den kraftige mand med det buskede skæg, skipper Warming. Nr. 3 fra venstre er 'CHRISTINE «s bedstemand, Jens Petersen, der siden hen selv blev skipper og endte sine dage som havnefoged i Egernsund. I baggrunden ses "CHRISTINE $\$ S$ master og til højre Gidals rambuk ng en slettoppet skonnert.

Den tunge kanon blev ved hjælp af taljer og ruller bakset op i Nissens have, hvor den var en yndet attraktion, indtil det rygtedes, at kromanden omgikkes med planer om at sende den til Tøjhusmuseet $\mathrm{i}$ København. Så tog tyskerne uden så meget som et "med forlov" affære og bortførte kanonen til Berlin. Hvis det ikke havde været for fotografiets skyld, havde jeg næppe vovet at skrive denne historie. Nu har det ovenikøbet været af afgørende betydning ved at fastslå kanonens identitet, og jeg skylder fuldmægtig Honnens de Lichtenberg og kommandør Borg tak for at have været mig behjælpelig dermed. Det drejer sig om en kanon af typen M. 1773, 24-pundig, vægt 5000 pund, længde 2,90 meter, højde ved den tykke ende $\mathbf{0 , 5 3}$ meter. Af disse kanoner fandtes der en del på den danske flådestation i Glïckstadt, hvor de faldt i oprørernes hænder. Typen har aldrig været benyttet i danske kanonbåde, hvorimod det ligger ganske nær at antage, 
at de er blevet sat ombord i oprørernes "kriegsloggere", og at det er fra en af dem, kanonen ved Stevning Næs er bleven smidt over bord, hvilket Nis Nissen, der på det tidspunkt var 32 år gammel, var vidne til. Den omstændighed, at tyskerne, efter sidste århundredskifte bortførte kanonen til Berlin, behøver selvsagt ikke at være et yderligere bevis herfor.

\section{NOTER}

1. Parancelle rig: Rigget med kun én, forholdsvis kort, men meget svær mast, der førte et latinersejl på en megat høj rå og desuden et stort forsejl på en lang bom fra masten og et godt stykke udover stævnen. 